\title{
Competitive Ability of Russian Economy on Macroeconomic Level
}

\author{
Grigoriy Artyomovich Balyhin ${ }^{1}$, Vladimir Borisovich Alekseenko ${ }^{1}$, Natalya Uryevna Sopilko ${ }^{1}$, Ekaterina \\ Alexandrovna Zhyravleva ${ }^{1} \&$ Gozel Muradovna Kutlyeva ${ }^{1}$ \\ ${ }^{1}$ Peoples' Friendship University of Russia, Moscow, Russia \\ Correspondence: Sopilko N. U., Ordzhonikidze str., 3, Moscow, 115419, Russian Federation.
}

Received: February 28, 2015 Accepted: March 20, 2015 Online Published: April 24, 2015

doi:10.5539/res.v7n6p46

URL: http://dx.doi.org/10.5539/res.v7n6p46

\begin{abstract}
The main problems of formation of national competitiveness caused by a low innovative development of the Russian Federation in the world rating in the current microeconomic trends have been analyzed in this article. Indexes of branch efficiency, dynamics of hi-tech exports, realization of opportunities of production and human potential allowing to evaluating the level of implementation of industrial and human development within a particular industry under the influence of macro-environment factors are being tracked. Here are defined ways of increasing economic efficiency of national economy and obtaining competitive advantages in market conditions.
\end{abstract}

Keywords: competitiveness of the country, macro-environment factors, production potential, foreign investments, innovation, human potential

\section{Introduction}

Nowadays the Russian economy is under the influence of many destabilizing factors and the choice of the most effective forms of its development which is actively taking part in the world production, technological and investment processes becomes the major purpose and a strategic guidelines of managing Russia. Current macroeconomic trends of economic globalization promote intensification of interdependence between the countries. They demand from the countries to fully account the directions of transformation and development of alternative competitive strategy when forming a scientifically based state policy of production development and ensuring a certain level of national competitiveness. (Kryukova et al., 2013, 2014)

As it is noted in the last report of UNCTAD, many countries have been aiming at strengthening the production potential today, encouraging and supporting foreign investments and also, on the contrary, strengthening norms of regulation of foreign investments. Thus, they develop strategically important sectors of the industry, toughening procedures of selection and monitoring associations and carefully checking the international mergers and acquisitions. The tendency of increasing volumes of investment into raw and infrastructure sectors is observed. It is connected with an aggravation of the global competition, with attempts of redistribution of the world markets and essential strengthening of positions of the developing countries. Within the given tendency, the realization of big and too big investment projects is enabled. It is possible to distinguish, for example, construction of new pipelines by Russia running to Europe as an attempt of diversification of ways of gas supply. Also China, Japan and other countries are creating national payment systems to decrease independence on the world monopolies in this sphere, etc. Sometimes scales of such projects demand participation of several countries. So, for example, the biggest project in the world is the construction of production system on natural gas extraction and its transportation from Russia to China which is estimated by experts at 77 billion dollars, Russia is going to invest 55 billion dollars and China—22 billion dollars (Druginin, 2014).

Within the above described tendency the hidden features of the gain trade and, as a result, investment protectionism which consists in replacement of foreign competitors from the national markets and creation of opportunities for development of national import-substituting productions started being shown. So, for example, China is looking into the possibilities of banning the usage of the servers IBM, Cisco, Qualcomm under the pretext of fight against cyber-espionage. According to forecasts of Forrester Research, in 2014 purchase of the IT equipment and technologies in China will grow by $11 \%$ to 125 billion dollars (Pavlov et al., 2014). Thus, the government of China creates such conditions under which the Chinese companies will be able gradually to drive the American competitors out of the market. Experience of application of ways of the hidden investment protectionism testifies that in most cases the national governments create conditions (tax, tariff, financial, etc.) 
for the national companies to enable them to successfully occupy niches from which foreign competitors were forced out.

For Russia, in this aspect, problems of economic growth, the improvement of quality of life of the population demanding development of national strategy in increasing competitiveness on a global scale are priorities. In this regard, a research objective is the analysis and identification of possible ways of ensuring national competitiveness of Russia on the basis of production development and human potential.

\section{Methods}

Scientific analytical publications and materials of the Russian and foreign experts, the state statistics data of Russia, the international organizations have formed procedural base of the research. For studying processes of improvement of national economy the standard methods of the analysis and generalization were used: structural, functional, comparative.

Being key concept of modern economic science, competitiveness of the country assumes variety of the existing approaches and estimates. Nowadays there is no created consensus among researchers concerning competitiveness of national economy. Many factors and dynamism of competitiveness make it difficult for scientists to fully understand its complicated structure (Sopilko, 2012). It may be noted that all modern theories on a problem of determination of national competitiveness accepted by a number of official organizations reflect basically M. Porter's theory based on evolution of concept of competitive advantage (Porter, 2012). According to this theory, competitive advantages of the country aren't inherited but created. Abundance of traditional factors of production isn't a sufficient condition for long-term competitiveness unless there are constant innovations and increase of labor productivity. The similar opinion is expressed by D. Dollar and E. Woolf who claim that the country combining prosperity in the international trade on the basis of more perfect technology and productivity with high income and salary is competitive (Dollar \& Wolf, 2003.) In addition to the given definitions, M. Dunn offers to understand competitiveness as flexibility with which the national economy is capable to expect structural changes and adapt for them in dynamic process (Dunn, 1990) T. Filosofova considers that the main directions of formation of competitive advantages of the country have to be correlated with national objectives (Filosofova, 2007).

In our opinion, national competitiveness can serve as the adequate reflection of economic efficiency of national economy in the market conditions including the competitive capacity of production branches and other spheres of economic activity and defining position of the country in the world ratings regarding its economic and political status.

\section{Results}

World financial and economic crisis showed that the ways of increasing competitiveness of economy demand a new assessment of economic activity of the state and business. (Zaernjuk et al., 2013) In the conditions of open economy submitting to norms of liberal globalization, development of any country is defined by taking full account of influence and a combination of internal and external factors. The mobilizing influence of factors of a macro-environment expresses need of carrying out an effective competition policy of the country. It should work at domestic market through increase of competitiveness of the domestic production in relation to import one (with development of production and human potentials) and by perception of national products in hi-tech export on the external market. The sequence of formation stages of competitiveness under the influence of macro-environment can be presented in the form of the scheme (Figure 1). 


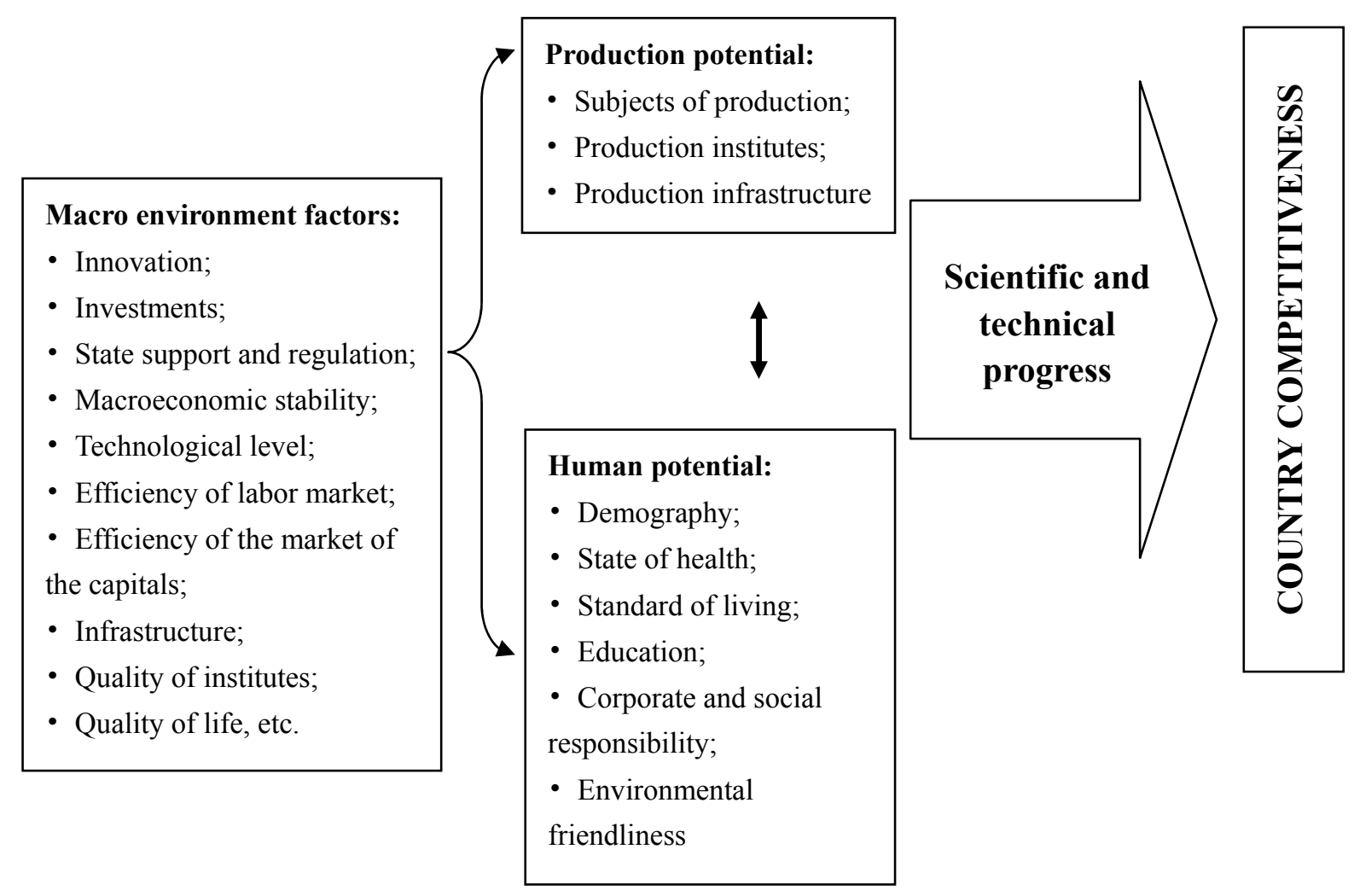

Figure 1. Interrelation of basic elements forming the country's competitiveness

According to the scheme (Figure 1), competitiveness of the country is formed in the conditions of multiple-factor influence that finds reflection in its providing, interrelation and interdependence of all components of elements and also a strategic orientation on increase of level of economic development (social and economic effect and quality of life).

Weak attention to the degree of influence of these factors can put the country into the dependence when the key role belongs only to external sources (macroeconomic factors) in development of national economy (Navrotskaya, 2013).

It is obvious that the economy of the country develops in those directions from where the demand comes from owing to external dependence of the country. If demand comes from the interested side in purchasing raw materials at limited quantity of other competitive part in the world production markets, it inevitably results in a hypertrophy of a raw complex which starts dominating in economy. Predicting growth rates of the Russian economy, it is necessary to consider the fact that in many respects growth of its GDP depends on the universal economic environment and demand for main types of natural raw materials. The world markets of these raw materials are subject to considerable tactical price fluctuations that lead to the increased risks. It is possible to improve a situation if along with the growth of production and export of raw material volumes of its processing are increased leading to growth of economic activity and will allow to making production with a bigger value added. Besides, the national economy needs essential investments as the production infrastructure in a number of sectors is extremely worn-out that causes falling of efficiency and outputs.

\section{Discussion}

The raw potential development of Russia is close to exhaustion, the country didn't manage to create competitive economy as it was noted by the Russian leaders at the January forum in Davos (2013). These facts are confirmed by low ratings of competitiveness. So, in 2013 in a world rating on national competitiveness, Russia ranked 67th out of 144 countries (next to Iran \& Sri Lanka), there is a tendency of decreasing its position (the 63rd position in 2010) (World Economic Forum: The Global Competitiveness Report 2012-2013).

The economy of Russia also strongly lags behind many countries of the world on the innovation level. It differs in high resource-consuming that is expressed not only in the low productivity (specific expenses of work), but also in a high material capacity of production (specific expenses of raw materials and materials). The 
consumption of fuel, metals, electric power and other types of resources in the country is known (on account of a large supply of natural riches) several times is more than in the developed countries, especially where there are almost no stocks of natural resources (Japan, Finland, etc.).

Positive dynamics of growth of an index of human development is observed in 2010-2013, in 2013 Russia ranked $55^{\text {th }}$ between Kuwait and Romania (there was an increase of an indicator of IChRP on 11 positions). Indicators of domestic innovation are characterized by rather low value. By calculations of the World economic forum in the world rating in 2013 Russia ranked 85th out of 144 countries, its scientific and technical achievements are too small in comparison with the most technologically successful states of the world: the USA, Sweden, Japan, China and Germany.

Increase of competitiveness in Russia is happening in the conditions essentially different from the world practice. However, the assessment of a level of development of society in Russia certainly is subject to macro-influence of the international technological transformations as the latest technologies are the integral component of progress of mankind.

The problem is that the process of formation of the large knowledge-intensive companies and organizations of small innovative business happens too slowly in the Russian state. The general macroeconomic conditions promoting innovations haven't been created: lack of the dynamic competition, deficiency of investment resources, high level of corruption.

\section{Prospects of Ensuring Competitiveness on the Basis of Innovative and Investment Development}

The most developed countries of the world have already been searching for main technologies for transition to a new technological era for a long time. Specialists forecast at present rates of technical and economic development, the sixth technological way (TW) will start being made out in 2010-2025 and a phase of a maturity will enter in the 2040th. Thus, in 2020-2025 there will be a new scientific, technical and technological revolution based on the development synthesizing achievements of the basic directions called above (Cabalov, 2010). In this regard, it should be noted that in the Russian economy so far even the fifth TU didn't become dominating. In the USA, for example, the share of productive forces of the fifth TU makes $60 \%$, the fourth TU- $20 \%$. About $5 \%$ already fall on the sixth TU. The share of technologies of the fifth way in Russia makes about $10 \%$ only in the most developed branches so far: in military industrial complex and the aerospace industry. More than $50 \%$ of technologies belong to the fourth level and nearly a third - to the third. Therefore the science and technologies are faced by rather complex challenge: within the next 10 years to be among the states with the sixth $\mathrm{TU}$, the economy of Russia needs to step over the fifth technological way.

The catching-up development and transition through technological way demand enormous mobilization of a national resource. So, South Korea at the price of social restrictions became one of the leaders of the fifth technological way.

Search for adaptation mechanisms of national economies to the new technological purposes is extremely important for Russia in such conditions. At the beginning of the 90ies of the XX century the system, as economic practice shows, had essential shortcomings in these countries but in general it was created and focused on technological development and its results advanced the Western countries in many branches. As experiment shows, Russia couldn't adapt its market-based system to essential innovation susceptibility for the last 20 years. Russia seems not to manage to carry out essential technological break to the sixth technological way by its own efforts. In this regard, strengthening, first of all, economic investment interactions within the integration associations promoting scientific technological, production and resource complement and inflow of foreign investments can become one of the significant and necessary measures of maintenance of national competitiveness.

Of course, Russia is interested in investments from the advanced countries which can promote essential technological updating and alongside with direct investments the country the recipient receives new technologies. However, in practice it is far not so as newly opened foreign enterprises often become the closed isolated enclaves and access to its technologies remains not available (Navrotskaya, 2012). Besides, the theory of life cycle of product by M. Porter testifies that not the most progressive technological production will be transferred. Besides, in the conditions of incompleteness of institutional transformations in Russia, weak development of infrastructure in it, the western investors don't prefer constructing new enterprises from scratch (the concept of a green lawn - greenfield development), but purchase existing successful enterprises which can effectively work without carrying out technological modernization.

Loukas's Paradox can serve as one more theoretical and empirically proved argument not in favor of effective 
western investments into the Russian economy (Lucas, 1990). According to approvals of the classical economic theory, the investment capital has to flow from the rich countries having surplus of the capital to the poor countries lacking investment resources and having higher rate of return. According to this paradox, investment resources, actually, move from the rich countries to the rich ones, in other words, to those countries which show high rates of economic development. Thus, the vicious circle turns out: to get high-tech (qualitative) investments, we've got to have the high-tech enterprises and high rates of development of economy. In this regard, Russia can count on investments in a bigger measure from the countries having approximately the same level of development. And taking into account effect of the neighbourhood-one more important empirically proved paradox (Kuznetsov, 2008), such countries must have geographical, possibly, ethnic, language and other proximity that also testifies need in an intensification of investment cooperation of complementary, neighboring countries.

At the present stage Russia lags behind average values of the developed countries of the world by the main criteria of innovative development. The indicator of innovative activity of the Russian industrial enterprises is less than $10 \%$. At the same time the average value on the EU is at the level of $44 \%$. By number of demands for inventions per capita Russia concedes to the USA and Germany by 3-5 times. It doesn't stimulate introduction of modern technologies and leads to attenuation of technical progress (Ivanova, 2008).

Low level of innovative activity in the industrial sphere is the main reason for essential reduction of a share of hi-tech export. According to the World bank, part of export of Russia in the world knowledge-intensive market is insignificantly small (0.3-0.5\%), it is much more lower than Mexico and Philippines have (not highly developed countries). Schedules of change of volumes of hi-tech export of some countries of the world during the period from 1996 to 2012 are submitted in Figure 2. (World Bank, 2014)

According to the presented data (Figure 2), the production and technological condition of Russia on indicators of innovative activity and a susceptibility of enterprises, technological level of production is characterized by considerable lag from the leading countries of the world. One of the main reasons for such situation is an unused organizational and resource potential of scientific and technological cooperation of Russia with other countries which forms industrial power, provides technological development of national economy.

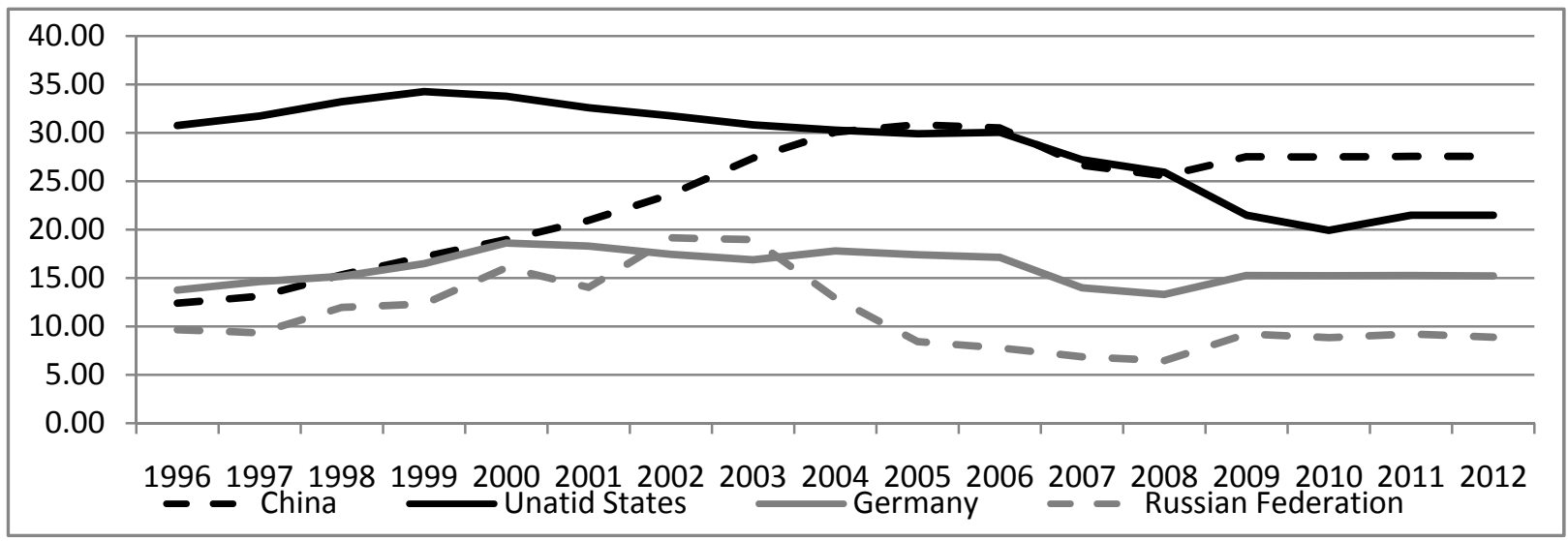

Figure 2. Dynamics of indicators of hi-tech export of a number of countries of the world (\% of export of industrial goods)

\section{Formation of Competitiveness on the Basis of Human Development}

The effective human (labor) potential and complementary production may serve as the important factor causing high national competitiveness (Figure 1).

Labor potential is understood as qualitative and quantitative expression of people's ability to physical, intellectual and spiritual creative activity (Zhuravleva, 2013). As qualitative characteristics may be considered a state of health, physical and psychophysical potential, volume of the general and special knowledge, labor skills, abilities and creativity, universal key competences (high adaptability; ability to study; skills of effective and cross-cultural communication, ability to work in team and effectively to cooperate; aspiration to improve a professional level, "environmental friendliness"), and also loyalty towards the company and social responsibility. 
Qualitative characteristics of labor potential at the macroeconomic level are:

- Demographic indicators (reflect gender and age structure of the population, death rate, life expectancy);

- State of health (the incidence testifies, negotiability to medical institutions, number of disabled people);

- A standard of living (shows the income level, percent of people with alcoholic and drug addiction, etc.);

- Education (number of people with the higher, incomplete higher, secondary general professional education and also people without education) (Gennaioli et al.,2013; Ghosh \& Mastromarco, 2013);

- Indicator "corporate social responsibility" (percent of the organizations having the effective programs including corporate social problems)

- "Environmental friendliness" (it is characterized by share of the organizations in use of "green" technologies and nature protection actions).

For a more complete understanding labor potential, it is necessary to specify what an indicator "corporate social responsibility" includes. Interpretation of such concepts as "corporate responsibility" and "corporate social responsibility" in relation to Russia was presented in the Report prepared by the Program of development of the UN (PROON) and Association of managers of Russia.

According to these documents, (Litovchenko et al., 2004), corporate responsibility is differentiated on corporate social responsibility and business. The first one is a complex indicator and it is defined as philosophy of behavior and the concept of forming their activities by business community, separate corporations and enterprises in the following directions:

- Production of qualitative products and services for consumers;

- Creation of attractive workplaces, payment of legal salaries, investments into human development;

- Observance of requirements of the legislation: tax, ecological, labor, etc.;

- Effective business focused on creation of the added economic cost and growth of welfare of the shareholders;

- Accounting of public expectations and general ethical standards of business management in practice;

- A contribution to formation of civil society through partner programs and projects of development of local community.

Corporate responsibility of business is defined in the considered report more narrowly as a voluntary contribution of the private sector to social development by social investments. They include material, technological, administrative and other resources and also financial means of the companies. All these resources according to the decision of the management go for implementation of the social programs which are developed taking into account interests of the main internal and outer interested parties, in the assumption, the company will receive (though not always and not simply measured) social and economic effect in the strategic relation (Reports, 2013, 2004).

The quantitative characteristic of labor potential at the macroeconomic level is the number of the efficient population of the country.

The wide range of qualitative and quantitative characteristics of labor potential assuming various aspects of human capabilities plus creative ones can significantly influence on formation of competitiveness of the country.

To estimate the level of realization of labor potential opportunities we offer to use an indicator-the index of branch efficiency (IBE) or the relation of gross additional cost of production received within a certain branch to number of the workers involved in it. Such indicator will help to characterize efficiency of activity in the concrete branch. To except influence on this index of an inflation factor we suggest using the gross additional cost (GAC) in the base prices. So, Figure. 3 presents dynamics of this indicator for manufacturing industry of the Russian Federation from 2005 to 2013 (VDS is presented in the prices of 2008) (Gennaioli et al., 2013; Kaurova et al., 2013, 2014). 


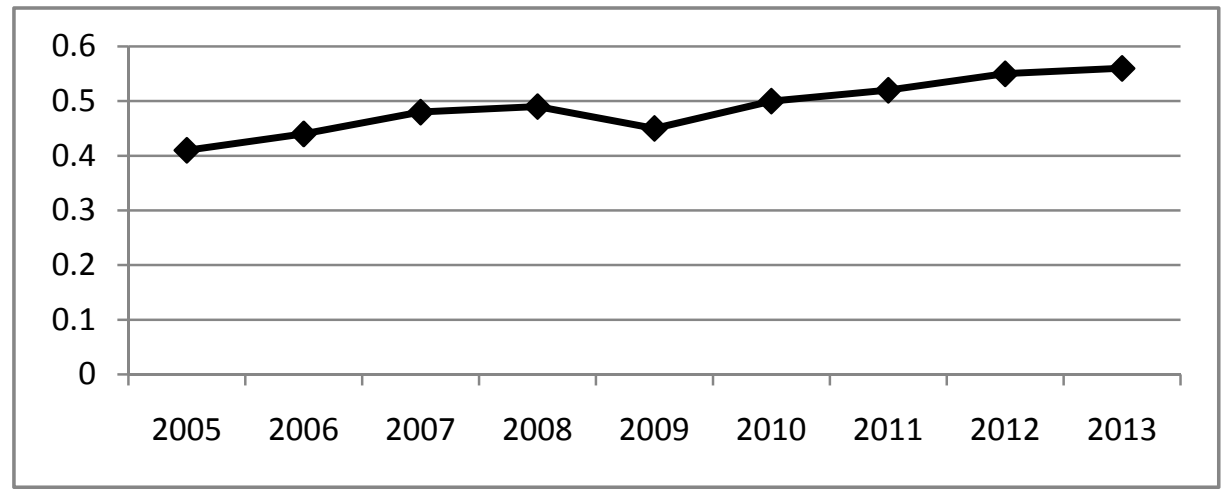

Figure 3. Dynamics IBE for manufacturing industry of the Russian Federation (one billion rub/thousand people)

The presented curve (Figure 3) testifies stable increase of efficiency of activity within this branch: obvious growth of an indicator of IBE is observed (an exception is the falling in 2009 as a result of world financial crisis).

Further it is of interest to compare these indexes in different countries of the world, to reveal branches-leaders, and then, having analysed factors of influence to create model of "ideal branch".

\section{Conclusion}

In the conclusion it is possible to allocate the main problems which are the reasons interfering increase of competitiveness of the Russian Federation in the world rating: low level of innovative development of the country, the need for investments caused by deterioration of production infrastructure, low quality of life, etc. (Kryukova et al., 2013, 2014).

The objective assessment of a technological condition of Russia in the context of evolution of scientific and technical progress demands development of national strategy of increasing competitiveness on a global scale. Thus, creation of the competitive advantages of national economy defining the status of the country and prospect of its development is important.

In this regard, increase of technological level of industrial branches can act as a positive factor for the state economy and formation of its adaptation opportunities. Development of production capacity of the country is possible on the basis of expansion of the intersectoral collaboration at various levels which will allow to use rationally resources and to provide a continuity of reproduction process, creating a set of additional effects in the market competitive environment.

Low level of innovative activity in the industrial sphere led to essential reduction of a share of hi-tech export. It is connected with insufficient use of organizational and resource potential of scientific and technological cooperation of Russia with other countries.

The presented dynamics of an index of the branch efficiency allowed us to estimate the level of realization of opportunities of the human potential complementing production within a certain branch, revealed stability testifying a sufficient reserve resource and can significantly influence on formation of national competitiveness.

Thus, more complete study of the ways to increase competitiveness of the Russian Federation based on the complex use of production and human potentials at the macroeconomic level seems actual to be represented for further researches.

\section{Reference}

Dollar, D., \& Wolf, E. (2003). The Global Competitive. Journal of International Economics, 27(3-4), 199-220.

Druginin, A. (2014) The Russian Federation invests within the gas contract $\$ 55$ billion, China $-\$ 22$ billion. RIA Novosti. Retrieved from http://ria.ru/economy/20140521/1008710605.html\#ixzz32wpbOJln

Dunn, M. (1990) The Economic of Modern Manufacturing: Technology, Strategy and Organization. American Economic Review, 80, 511-528.

Elena, M. K., Sergey, L. R., \& Ekaterina, A. V. (2014). Mono-Town in the System of Economic Notions of the Russian Federation. World Applied Sciences Journal, 27, 162-166.

Filosofova, T. G., \& Bykov, V. A. (2007). Competition and competitiveness. Moskow, M: UNITY-DANA. 
Gennaioli, N., et al. (2013). Human capital and Regional development. The Quarterly Journal of Economics, 128(1), 105-164. http://dx.doi.org/10.1093/qje/qjs050

Ghosh, S., \& Mastromarco, C. (2013). International economic activities, human capital and efficiency: A stochastic frontier analysis for OECD countries. Global economy, 36, 761-785.

Ivanova, N., et al. (2008). The analysis of innovative policy of Russia and Ukraine on methodology of the European Community. Moskow, M: IMEMO RAN.

Kaurova, O., Maloletko, A., Yumanova, O., Kryukova, E. M., \& Deryabina, A. V. (2014). Modern trends in development of tourism statistics in world and in Russia. Life Science Journal, 11(4), 451-454.

Kaurova, O., Maloletko, A., \& Yumanova, O. (2013). Cross-country Comparison of Statistical Indicators. Life Science Journal, 10(4), 1915-1917.

Kryukova, E. M., Makeeva, D. R., Atamanova, M. A., \& Shadskaja, I. G. (2013). Financial mechanism of housing and utilities infrastructure. Life Science Journal, 10(4), 790-794.

Kryukova, E. M., Makeeva, D. R., \& Konovalov, E. E. (2014) Tourism as Preferred Direction in the Strategy of Substitution of Industry Branches in Mono-Territories of Russian Federation. World Applied Sciences Journal, 30, 176-178.

Kryukova, E. M., Novikova, N. G., Zikirova, S. S., \& Podsevalova, E. N. (2014). Financial support of the formation of social housing in Russia and Abroad. World Applied Sciences Journal, 30(12), 1746-1748.

Kuznetsov, A. (2008). Direct foreign investments: "Effect of the neighbourhood". World economy and international relations, 9, 40-47.

Litovchenko, S., et al. (2004). Report on Social Investments in Russia 2004. The role of business in social development. Moskow, M: Managers Association.

Lucas, R. (1990). Why Doesn't Capital Flow from Rich to Poor Countries? American Economic Review, 80, 93-96.

Navrotskaya, N. (2012). Dualizm of direct foreign investments. The Business Inform, 1, 67-71.

Navrotskaya, N. (2013). Transformation of world investment space in the conditions of globalization. Ekonomichny chasopys, XXI(3-4), 37-40.

Official site of the World bank. (2014). Retrieved April 11, 2014, from http://www.data.worldbank.org/indicator/

Pavlov, V., et al. (2014). China can forbid the IBM servers after a spy scandal with the USA. RBC whole world. Retrieved from http://top.rbc.ru/economics/27/05/2014/926640.shtml

Porter, M. E. (2012). Competitive Advantage: Creating and Sustaining Superior Performance. New York, NY: Simon and Schuster.

Sopilko, N. (2012). Regional integration as a factor to increase competitiveness of national economy. Bulletin Economy series, 3, 51-60.

World Economic Forum: The Global Competitiveness Report 2012-2013. (n.d.). Switzerland: Geneva.

Zaernjuk, V. M., Kryukova, E. M., Bokareva, E. V., \& Chernikova, L. I. (2014). Study of theoretical approaches banking financial intermediation and directions of its development in Russia and Abroad. World Applied Sciences Journal, 30(12), 1746-1748.

Zhuravleva, E. (2013). Labor potential as basis of formation of corporate culture. KEU Bulletin, 4(27), 104-106.

\section{Copyrights}

Copyright for this article is retained by the author(s), with first publication rights granted to the journal.

This is an open-access article distributed under the terms and conditions of the Creative Commons Attribution license (http://creativecommons.org/licenses/by/3.0/). 